\title{
Differential response of phosphorus utilization efficiency in rice by tracer technique using phosphorus-32 under phosphorus stress environment
}

\author{
V. Sanjivkumar* and P. Malarvizhi \\ Department of Soil Science and Agricultural Chemistry, Tamil Nadu Agricultural University, Coimbatore - 641003 \\ (Tamil Nadu), INDIA \\ *Corresponding author. E-mail: sanjivkumarv@ rediffmail.com
}

Received: April 04, 2014; Revised received: April 27, 2014; Accepted: September 20, 2014

\begin{abstract}
In most soils, soil and fertilizer Phosphorus $(\mathrm{P})$ are easily bound by either soil organic matter or chemicals and thus are unavailable to plants unless hydrolyzed to release inorganic phosphate. Therefore, the development of $\mathrm{P}$-efficient rice varieties that can grow and yield better with low $\mathrm{P}$ supply is a key to improve crop production. $\mathrm{P}$ efficient plants play a major role in increasing crop yields due to shortage of inorganic $P$ fertilizer resources, limited land and water resources and increasing environmental concerns. Based on the P uptake efficiency, four rice genotypes viz.,TNRH 180, CB08504, CB06732 and ADT 47 were selected from the field experiment and used in pot culture experiment with three levels of $P$ using radio isotope technique to quantify the $P$ acquisition efficiency (PAE) and $P$ use efficiency (PUE) and also to determine the native $P$ supplying power of the soils using ${ }^{32} P$ in low $P$ soils. Growth and yield parameters, grain and straw yield and major nutrients uptake of rice genotypes were increased with enhanced level of phosphorus application. Among the four genotypes, TNRH 180 recorded the highest grain yield and uptake. Increasing the $\mathrm{P}$ application rate from 25 to $50 \mathrm{~kg} \mathrm{P}_{2} \mathrm{O}_{5}$ ha ${ }^{-1}$ increased the \% Pdff in grain and straw for all the genotypes. The mean per cent phosphorus utilization (PPU) ranged between 18.74 and 23.72. The PPU of the genotypes followed the order TNRH $180(23.72 \%)>$ CB08504 (23.36\%) > CB06732 (20.54\%) > ADT $47(18.74 \%)$. The PPU values were higher at lower level of $\mathrm{P}$ application $\left(25 \mathrm{~kg} \mathrm{P}_{2} \mathrm{O}_{5}\right.$ ha $\left.{ }^{-1}\right)$ for the genotypes TNRH 180, CB08504 and CB06732. From this study showed that rice genotypes have the ability to utilize the both available and unavailable form of phosphorus by secreting some organic acids in the root portion to solubilize. Hence rice genotypes indicated above have the ability to increase phosphorus utilization efficiency.
\end{abstract}

Keywords: Pdff, Pdfs, Phosphorus-32 ( $\left.{ }^{32} \mathrm{P}\right), \mathrm{P}$ utilization, Rice, Yield

\section{INTRODUCTION}

Rice is the most important staple food for more than half of the world population, including region of the high population density and rapid growth. It provides about $21 \%$ of the total calorie intake of the world population. Rice production is concentrated in Asia, where more than $90 \%$ of the world supply is produced. China and India are the leading producers as well as consumers of rice. The recent scenario (Motsara, 2002) revealed that in India the soils of $42 \%$ of the districts are in low $\mathrm{P}$ category $38 \%$ in the medium category and $20 \%$ districts are in high $\mathrm{P}$ category. Phosphorus deficiency has been identified as one of the major limiting factors for rice production mostly in highly weathered soils such as oxisols and ultisols. High phosphorus fertilization is necessary to obtain good yield on these soils (Kaushik et al., 2004). However, farmers are facing difficulties due to increasing costs of fertilizers, especially in developing countries. Plants that are efficient in absorption and utilization of the absorbed nutrients greatly enhance the efficiency of applied fertilizers (Tiwari, 2002). A more comprehensive understanding of the molecular and physiological basis of mineral nutrient uptake and utilization in plants is leading to strategies for development of better nutrient-efficient cultivars suited for optimal production with less fertilizer inputs. Adaptation of such cultivars with higher nutrient use efficiency is relatively easy, since no additional costs are involved and no major changes in cropping systems are necessary (Aziz et al., 2006). Therefore, the development of P-efficient crop varieties that can grow and yield better with low $\mathrm{P}$ supply is a key to improving crop production. Phosphorus-32 $\left({ }^{32} \mathrm{P}\right)$ is used in agriculture for tracking a plant's uptake of fertilizer from the roots to the leaves. Exploitation of genetic variation in plants in nutrient efficiency has been increasingly explored and emerging as a variable alternative approach to crop production in low nutrient environment (Basak and Dravid, 1992). With this view, an attempt has been made to exploit the rice genotypes for $\mathrm{P}$ acquisition (PAE) and use efficiency (PUE) and to quantify the PAE and PUE using ${ }^{32} \mathrm{P}$ in low P soils. 


\section{MATERIALS AND METHODS}

A pot culture experiment was conducted at Radio Isotope (Tracer) Laboratory, Department of Soil Science and Agricultural Chemistry, TNAU, Coimbatore. The pot culture experiment was laid out in the Completly Randomized Blocks Design (CRBD) with three phosphorus levels $\left(\mathrm{P}_{0}-0 \mathrm{~kg} \mathrm{P}_{2} \mathrm{O}_{5}, \mathrm{P}_{1}-25 \mathrm{~kg}\right.$ $\mathrm{P}_{2} \mathrm{O}_{5}$ and $\mathrm{P}_{2}-50 \mathrm{~kg} \mathrm{P}_{2} \mathrm{O}_{5} \mathrm{ha}^{-1}$ ) and four rice genotypes (TNRH 180, CB08504, CB06732 and ADT 47) with three replications along with the recommended dose of nitrogen and potassium. Nitrogen was applied as four equal splits viz., basal, active tillering, panicle initiation and flowering, full dose of phosphorus and potassium applied as basal application. Radioactive ${ }^{32} \mathrm{P}$ material was obtained as carrier free orthophosphoric acid in dilute hydrochloric acid medium from the Board of Radiation and Isotope Technology (BRIT), Mumbai and used for the study. The physical half life $\left(\mathrm{T}^{1 / 2}\right)$ of ${ }^{32} \mathrm{P}$ is 14.3 days. It decays into ${ }^{32} \mathrm{~S}$ by emitting negatrons $\left(\beta^{-}\right)$of $\mathrm{E}$ max $1.71 \mathrm{MeV}$. Phosphorus ${ }^{32}$ as labelled single super phosphate (SSP) was applied as basal to each pot. Labelled SSP was prepared by mixing together with constant stirring of calculated quantities of rock phosphate, ${ }^{32} \mathrm{P}$ stock solution and concentrated $\mathrm{H}_{2} \mathrm{SO}_{4}$. The material was cured under heating infrared lamp to dryness and then ground to a fine powder with a pestle and mortar. These radioactive fertilizers were applied to the pots by taking all precautions stipulated for handling the isotopic materials. Pots were irrigated and kept under submerged condition and 22 days old seedlings raised in nursery bed were transplanted @ 23 seedlings per pot. Plant samples were collected at harvest stage. The collected samples were dried in a hot air oven at $65{ }^{\circ} \mathrm{C}$ and the dry weight was recorded. The oven dried plant materials were chopped and grounded in a Willey mill and stored in wide-mouthed stoppard bottles. After suitable sub sampling, the samples were analyzed for total phosphorus by Vanadomolybdate yellow colour method (Piper, 1966). The radioactivity in the plant digest was determined as suggested by (McKenzie and Dean, 1948) using an end -window Geiger Muller counter (Type Para Nuclear Counter PNC 1a).

Radio assay data were converted into different parameters by using following formulae.

Corrected count rate per second

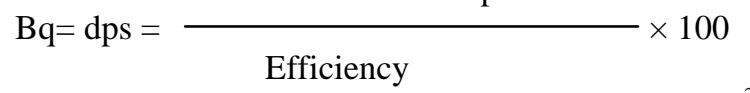

The efficiency of the Geiger muller counter used for ${ }^{32} \mathrm{P}$ counting was 7 per cent.

Disintegration rate in sample (dps)

$\begin{aligned} & \text { Specific activity }= \\ & \left(\mathrm{dps} \mathrm{mg} \text { of } \mathrm{P}^{-1}\right)\end{aligned} \quad$ P content in sample $(\mathrm{mg})$

$$
\% \text { Pdff }=\frac{\text { Specific activity of plant sample }}{\text { Specific activity of fertilizer standard }} \times 100
$$

$\%$ Pdfs $=100-\%$ Pdff

(Pdff $=$ phosphorus in the plant derived from applied fertilizer); (Pdfs = phosphorus in the plant sample derived from soil)

Uptake from applied source $\left(\mathrm{mg} \mathrm{P} \mathrm{pot}^{-1}\right)=(\%$ Pdff / 100) $\mathrm{x}$ Total $\mathrm{P}$ uptake $\left(\mathrm{mg} \mathrm{P} \mathrm{pot}^{-1}\right)$

$\% \mathrm{P}$ utilization $=\{$ Uptake from applied fertilizer $(\mathrm{mg}$ $\left.\mathrm{P} \operatorname{pot}^{-1}\right) / \mathrm{P}$ applied through fertilizer $\left(\mathrm{mg} \mathrm{P}^{\mathrm{P}}\right.$ pot $\left.^{-1}\right) \times 100$ The initial soil sample collected from the experimental site before the commencement of experiment was analyzed for the various physico-chemical properties. The soil was clay in texture. The cation exchange capacity of the soil was $17.0 \mathrm{c}$ mol $\left(\mathrm{P}^{+}\right) \mathrm{kg}^{-1}$ and the organic carbon content was $0.40 \%$. The soil $\mathrm{pH}$ was alkaline (8.29) and non-saline EC $\left(0.30 \mathrm{dSm}^{-1}\right)$. The available nitrogen, phosphorus and potassium content of the soil was low, low and medium fertility status (176.2, 5.62 and $330 \mathrm{~kg} \mathrm{ha}^{-1}$, respectively).

\section{RESULTS AND DICUSSION}

In present study it was observed that grain yield in rice genotypes revealed distinct differences between the genotypes. Among the rice genotypes, grain yield showed a gradual increase when applied with higher level of phosphorus (19.1 to $23.5 \mathrm{~g} \mathrm{pot}^{-1}$ ). The mean value of grain yield was higher in TNRH-180 and CB06732 (22.3 $\left.\mathrm{g} \mathrm{pot}^{-1}\right)$ and lowest value was recorded in CB08504 (18.7 $\mathrm{g} \mathrm{pot}^{-1}$ ) (Fig 1 and 2 ). The interaction effect of rice genotypes at phosphorus levels was not significant. Gradual increase in grain yield in rice genotypes when applied with higher level of phosphorus might be due to application of organic source along with inorganic nutrients. Higher grain yield with $\mathrm{N}, \mathrm{P}$ and $\mathrm{K}$ application may be attributed to more number of filled grains panicle ${ }^{-1}$, higher panicle weight and 1000 grain weight. Bali et al. (2006) reported that application of $16.5 \mathrm{~kg} \mathrm{P} \mathrm{ha}^{-1}$ increased grain yields of rainfed lowland rice to about 2.5-3.0 $\mathrm{tha}^{-1}$ on a sandy soil. The current results corroborates with the findings of Shen et al. (2011) who observed that unique characteristic of $\mathrm{P}$ is its low availability due to slow diffusion and high fixation in soils causing it a major limiting factor for plant growth.

In present study it was observed that the straw yield revealed distinct differences between the genotypes and there was a gradual increase for increased level of phosphorus application. The mean value of straw yield was higher in CB06732 (30.1 $\mathrm{g} \mathrm{pot}^{-1}$ ) and the lowest value was recorded in CB08504 (26.5 $\mathrm{g} \mathrm{pot}^{-1}$ ). The interaction effect of different genotypes at phosphorus levels was significant and among the rice genotypes, CB06732 recorded the highest straw yield $\left(34.0 \mathrm{~g} \mathrm{pot}^{-1}\right)$ followed by ADT 47 (33.1 $\left.\mathrm{g} \mathrm{pot}^{-1}\right)$ at higher dose of $\mathrm{P}\left(50 \mathrm{~kg} \mathrm{P}_{2} \mathrm{O}_{5} \mathrm{ha}^{-1}\right)$ and the lowest value was registered in CB08504 (22.9 $\left.\mathrm{g} \mathrm{pot}^{-1}\right)$ when phosphorus was not applied. The increase in grain and straw yield might be due to over all improvement in plant growth as it plays an important role in plant metabolism and resulting in better yield. Yadav et al. 
(2002) emanated that application of 100 percent $P$ with $\mathrm{N}$ and $\mathrm{K}$ increased the dry matter production at all the growth stages and further due to increased plant height, tiller number and improved vegetative growth. Genotypes exerted a significant effect on \%Pdff in grain. Among the genotypes, CB06732 recorded significantly higher \%Pdff at both the levels of $\mathrm{P}$ application. Increasing the $\mathrm{P}$ application rate from 25 to $50 \mathrm{~kg} \mathrm{P}_{2} \mathrm{O}_{5} \mathrm{ha}^{-1}$ increased the \%Pdff for all the genotypes. Interaction effect was also found to be significant. The highest \%Pdff was recorded for the genotype TNRH $180 \quad(14.85 \%$ and $13.93 \%$, respectively in grain and straw). Increasing the levels of $\mathrm{P}$ increased the \%Pdff for all the genotypes except for CB08504 (Table 1).

Genotypes and levels of $\mathrm{P}\left(25\right.$ and $\left.50 \mathrm{~kg} \mathrm{P}_{2} \mathrm{O}_{5} \mathrm{ha}^{-1}\right)$ showed significant influence on $\%$ Pdfs in grain and straw. Among the genotypes CO 06732 recorded highest per cent of \%Pdfs in grain. The mean \%Pdfs ranged from $85.15 \%$ (TNRH 180) to $90.49 \%$ (CB06732) in grain and $86.08 \%$ (TNRH 180) to $88.95 \%$ (ADT 47) for straw. In the case of grain the \% Pdfs was $89.64 \%$ at $25 \mathrm{~kg} \mathrm{P}_{2} \mathrm{O}_{5} \mathrm{ha}^{-1}$ and $83.36 \%$ at $50 \mathrm{~kg} \mathrm{P}_{2} \mathrm{O}_{5} \mathrm{ha}^{-1}$ respectively (Table 1 ).

Higher level of $\mathrm{P}$ application recorded higher $\mathrm{P}$ uptake from fertilizer both in grain and straw. Among the genotype CB08504 recorded significantly higher mean $\mathrm{P}$ uptake $\left(8.11 \mathrm{mg} \mathrm{pot}^{-1}\right)$ from fertilizer in grain than other genotypes where as the $\mathrm{P}$ uptake from fertilizer in straw was higher for CB06732 (9.03 mg pot ${ }^{-1}$ ). Interaction between genotypes and $\mathrm{P}$ levels was found to be significant. At lower level of $\mathrm{P}\left(25 \mathrm{~kg} \mathrm{P}_{2} \mathrm{O}_{5} \mathrm{ha}^{-1}\right)$ application the $\mathrm{P}$ uptake from fertilizer was highest for the rice genotype $\mathrm{CB} 08504$ (6.56 $\left.\mathrm{mg} \mathrm{pot}^{-1}\right)$ while at higher level of $\mathrm{P}\left(50 \mathrm{~kg} \mathrm{P}_{2} \mathrm{O}_{5} \mathrm{ha}^{-1}\right)$ application ADT 47 recorded higher $\mathrm{P}$ uptake from fertilizer $(10.95 \mathrm{mg}$ $\operatorname{pot}^{-1}$ ) (Table 2).

In the present study it was observed that PPU of the genotypes followed the order TNRH 180 (23.72\%) > CB08504 (23.36\%) > CB06732 (20.54\%) > ADT 47 (18.74\%). The PPU values were higher at lower level of $\mathrm{P}$ application $\left(25 \mathrm{~kg}_{2} \mathrm{O}_{5} \mathrm{ha}^{-1}\right.$ ) for the genotypes TNHR 180, CB08504, CB06732 (Table 2). The ability of the genotypes to absorb $\mathrm{P}$ from the native and applied source varied and it is not the same for all the genotypes. The increase in \% Pdff and the amount of $\mathrm{P}$ taken up from the fertilizer source with increased levels of $\mathrm{P}$ application might be due to increased availability of $\mathrm{P}$ in soil as assessed by conventional methods and precise estimation by ${ }^{32} \mathrm{P}$ studies leading to higher dry matter production. Basak and David, (1990) and Sudhir, (1996) studied that utilization of applied $\mathrm{P}$ by rice cultivars at tillering, flowering and harvest stage. At all the three stages he found the total $\mathrm{P}$ uptake and Pdff increased but PPU decreased with increased $\mathrm{P}$ levels (up to $60 \mathrm{~kg} \mathrm{P}_{2} \mathrm{O}_{5} \mathrm{ha}^{-1}$. Phosphorus

Table 1. Percent $\mathrm{P}$ derived from fertilizer (\%Pdff), the $\% \mathrm{P}$ derived from soil (\%Pdfs) in post harvest soil sample of the rice genotypes as influenced by different $\mathrm{P}$ levels.

\begin{tabular}{|c|c|c|c|c|c|c|c|c|c|c|c|c|}
\hline \multirow[b]{2}{*}{ Genotypes } & \multicolumn{3}{|c|}{ Pdff $\%$ grain } & \multicolumn{3}{|c|}{ Pdff \% straw } & \multicolumn{3}{|c|}{ Pdfs \% grain } & \multicolumn{3}{|c|}{ Pdfs \% straw } \\
\hline & $\begin{array}{c}25 \mathrm{~kg} \\
P\end{array}$ & $\begin{array}{c}50 \mathrm{~kg} \\
\mathrm{P}\end{array}$ & Mean & $\begin{array}{c}25 \mathrm{~kg} \\
\mathrm{P}\end{array}$ & $\begin{array}{c}50 \mathrm{~kg} \\
\mathrm{P}\end{array}$ & Mean & $\begin{array}{c}25 \mathrm{~kg} \\
\text { P }\end{array}$ & $\begin{array}{c}50 \mathrm{~kg} \\
\mathrm{P}\end{array}$ & Mean & $\begin{array}{c}25 \mathrm{~kg} \\
P\end{array}$ & $\begin{array}{c}50 \mathrm{~kg} \\
\mathrm{P}\end{array}$ & Mean \\
\hline $\begin{array}{l}\text { TNRH- } \\
180\end{array}$ & 12.74 & 16.96 & 14.85 & 13.83 & 14.02 & 13.93 & 87.26 & 83.04 & 85.15 & 86.17 & 85.98 & 86.08 \\
\hline CB08504 & 16.79 & 17.05 & 16.92 & 13.14 & 12.22 & 12.68 & 83.31 & 82.95 & 83.13 & 87.78 & 86.86 & 87.32 \\
\hline CB06732 & 5.01 & 14.02 & 9.52 & 10.99 & 15.57 & 13.28 & 94.99 & 85.98 & 90.49 & 89.01 & 84.43 & 86.72 \\
\hline ADT-47 & 7.01 & 18.55 & 12.78 & 8.76 & 13.35 & 11.06 & 92.99 & 81.45 & 87.22 & 91.24 & 86.65 & 88.95 \\
\hline \multirow[t]{2}{*}{ Mean } & 10.39 & 16.65 & 13.52 & 11.68 & 13.79 & 12.74 & 89.64 & 83.36 & 86.49 & 88.55 & 85.98 & 87.27 \\
\hline & SED & $\begin{array}{c}\text { CD } \\
(0.01)\end{array}$ & & SED & $\begin{array}{c}\text { CD } \\
(0.01)\end{array}$ & & SED & $\begin{array}{c}\text { CD } \\
(0.01)\end{array}$ & & SED & $\begin{array}{c}\mathrm{CD} \\
(0.01)\end{array}$ & \\
\hline$\overline{\mathbf{P}}$ & 0.147 & 0.311 & & 0.127 & 0.270 & & 0.890 & 1.887 & & 0.906 & 1.920 & \\
\hline $\mathbf{G}$ & 0.208 & 0.440 & & 0.180 & 0.382 & & 1.259 & 2.668 & & NS & NS & \\
\hline $\mathbf{P} * \mathbf{G}$ & 0.294 & 0.623 & & 0.255 & 0.540 & & NS & NS & & 1.812 & 3.840 & \\
\hline
\end{tabular}

Table 2. $\mathrm{P}$ uptake from fertilizer and the percent $\mathrm{P}$ utilization in post harvest soil sample of the rice genotypes as influenced by different P levels.

\begin{tabular}{|c|c|c|c|c|c|c|c|c|c|}
\hline \multirow{3}{*}{ Genotypes } & \multicolumn{6}{|c|}{ P uptake from fertilizer $(\mathrm{mg} / \mathrm{pot})$} & \multirow{2}{*}{\multicolumn{3}{|c|}{$\% \mathbf{P}$ utilisation }} \\
\hline & \multicolumn{3}{|c|}{ Grain } & \multicolumn{3}{|c|}{ Straw } & & & \\
\hline & $25 \mathrm{~kg} P$ & $50 \mathrm{~kg} P$ & Mean & $25 \mathrm{~kg} P$ & $50 \mathrm{~kg} P$ & Mean & $25 \mathrm{~kg} P$ & $50 \mathrm{~kg} P$ & Mean \\
\hline TNRH-180 & 6.11 & 8.55 & 7.33 & 8.15 & 8.92 & 8.54 & 29.42 & 18.01 & 23.72 \\
\hline CB08504 & 6.56 & 9.67 & 8.11 & 7.10 & 8.32 & 7.71 & 28.17 & 18.55 & 23.36 \\
\hline CB06732 & 3.21 & 6.81 & 5.01 & 8.52 & 9.53 & 9.03 & 24.21 & 16.86 & 20.54 \\
\hline ADT-47 & 3.10 & 10.95 & 7.03 & 4.95 & 9.28 & 7.12 & 16.61 & 20.87 & 18.74 \\
\hline \multirow[t]{2}{*}{ Mean } & 4.75 & 9.00 & 6.87 & 7.18 & 9.01 & 8.1 & 24.60 & 18.57 & 21.59 \\
\hline & SED & $\mathrm{CD}(0.01)$ & & SED & $\mathrm{CD}(0.01)$ & & SED & $\mathrm{CD}(0.01)$ & \\
\hline $\mathbf{P}$ & 0.076 & 0.161 & & 0.085 & 0.180 & & 0.227 & 0.481 & \\
\hline $\mathbf{G}$ & 0.107 & 0.227 & & 0.120 & 0.254 & & 0.321 & 0.681 & \\
\hline $\mathbf{P} * \mathbf{G}$ & 0.151 & 0.321 & & 0.169 & 0.359 & & 0.454 & 0.963 & \\
\hline
\end{tabular}




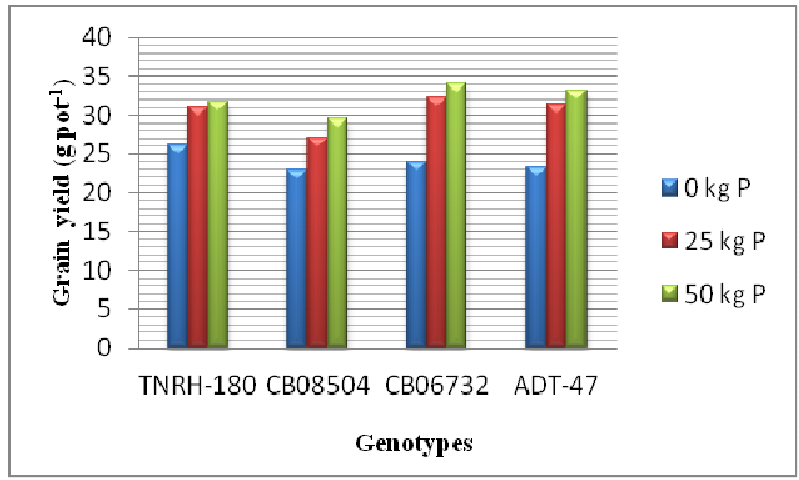

Fig. 1. Grain yield $\left(\mathrm{g} \mathrm{pot}^{-1}\right)$ of the rice genotypes as influenced by different $P$ levels

uptake from soil was found to be more at lower doses of $\mathrm{P}$ application. In present study, the reduction in PPU at $50 \mathrm{~kg} \mathrm{ha}^{-1}$ might be attributed to the higher release of native phosphorus in soil. The depression of PPU of ADT 47 may possibly be ascribed to the rhizopshere effect which appears to have solubilizing effect on native $\mathrm{Fe}, \mathrm{Al}$ and $\mathrm{Ca}$ phosphate and increasing the availability of native phosphorus. Richardson et al. (2011) reported that some plant species/genotypes alter the architecture of their root systems under $\mathrm{P}$ stress conditions to optimize $\mathrm{P}$ acquisition, therefore PPU were increased.

\section{Conclusion}

The result of the present study revealed that among the genotypes, CB06732 recorded significantly higher \% Pdff and \% Pdfs at both the levels of $\mathrm{P}$ application. Increasing the $\mathrm{P}$ application rate from 25 to $50 \mathrm{~kg} \mathrm{P}_{2} \mathrm{O}_{5}$ increased the $\%$ Pdff for all the genotypes. The genotype CB08504 recorded significantly higher mean $\mathrm{P}$ uptake (8.11 mg pot ${ }^{-1}$ ) in grain than other genotypes where as the $\mathrm{P}$ uptake from fertilizer in straw was higher for CB06732. The PPU of the genotypes followed the order TNRH $180(23.72 \%)>$ CB08504 $(23.36 \%)>$ CB06732 (20.54\%) > ADT 47 (18.74\%). Genomic approaches involving identification of expressed sequence tags (ESTs) found that under low-P stress and applied P may also yield target sites for plant improvement. Thus, from this scientific approach, farmers community can cultivate these rice genotypes under phosphorus stress condition and save $\mathrm{P}$ fertilizers and avoid to making fertilizers pollution to the soil ecosystem and maintain the soil fertility status.

\section{REFERENCES}

Aziz, T., Rahmatullah, M.A., Maqsood, M.A., Tahir, I. Ahmad and Cheema, M. A. (2006). Phosphorus

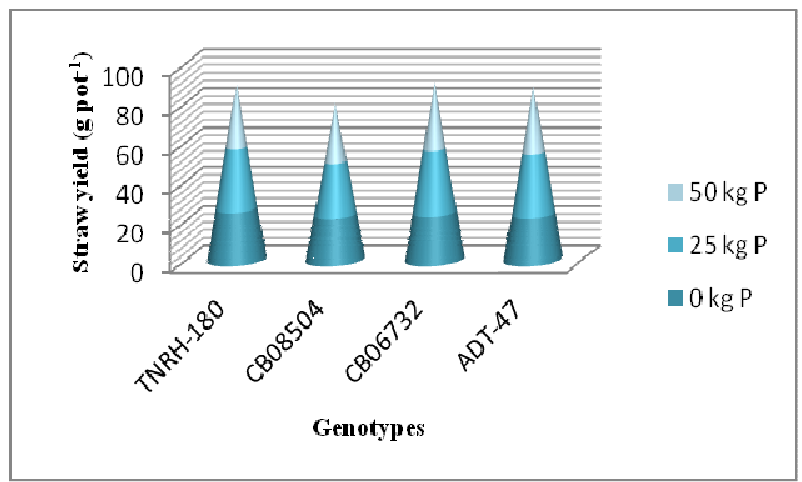

Fig. 2. Straw yield $\left(\mathrm{g} \mathrm{pot}^{-1}\right)$ of the rice genotypes as influenced by different $P$ levels

utilization by six Brassica cultivars (Brassica juncea L.) from tri-calcium phosphate; a relatively insoluble $\mathrm{P}$ compound. Pakistan Journal of Botany, 38: 1529-1538.

Bali, A. S., Singh, M., Kumar, A., Kachroo, D. and Sharma, B.C. (2006). Effect of nutrient management on yield and nutrient response of hybrid rice (Oryza sativa L). Journal of Research, 5(1): 78-83.

Basak, R. K. and Dravid, G. K. (1992). Residual effect of rock phosphate and basic slag on the yield of rice. Environmental Biology, 8(2): 750-751.

Kaushik, B. D., Mishra, B. N., Gautam, R. C. and Rana, A. K. (2004). P-Nutrition in rice wheat cropping system with microbial consortia. Annals of Agricultural Research. New Series, 25: 179-186.

McKenzie, A. J. and Dean, L.A. (1948). Procedure for measurement of ${ }^{31} \mathrm{P},{ }^{32} \mathrm{P}$ in plant materials. Anaytical Chemistry, 20:559-560.

Motsara, M. R. (2002). Available nitrogen, phosphorus and potassium status of Indian soils as depicyed by soil fertility maps. Ferilizer News, 47(8): 15-21.

Piper, C. S. (1966). Soil and Plant Analysis. Hans publisher, Bombay.

Richardson, A. E., Lynch, J. P., Ryan, P. R., Delhaize E., Smith, F. A., Smith, S.E., Harvey P. R., Ryan M. H., Veneklaas E. J., Lambers, H., Oberson, A., Culvenor R. A. and Simpson, R. J. (2011). Plant and microbial strategies to improve the phosphorus efficiency of agriculture. Plant and Soil, 349: 121-156.

Shen, J., Yuan, L., Zhang, J., Li, H., Bai, Z., Chen, X., Zhang, W. and Zhang, F. (2011). Phosphorus dynamics: From soil to plant. Plant Physiology, 156: 997-1005.

Sudhir (1996). Interaction effect of phosphorus and sulphur on uptake of nitrogen, phosphorus and potassium and sulphur by pigeon pea (Cajanus cajan). Indian Journal of Agronomy, 45(2): 348-352.

Tiwari, K. N. (2002). Phosphorus. In: Fundamentals of Soil Science. Indian Society of Soil Science, Cambridge Printing Works, New Delhi. pp: 353-368.

Yadav, S. K., Krick, G. J. D. and Santos, M. B. (2002). Proc. International. Conf. Managing Natural Resources for Sustainable Agriculture Production in the $21^{\text {st }}$ Century. New Delhi, 3, 871. 